\title{
Zinc and Taurine in Friedreich's Ataxia
}

\author{
D. Shapcott, R. Giguère, B. Lemieux
}

ABSTRACT: Zinc and taurine were measured in urine in the fasting state and following a $4 \mathrm{mg} / \mathrm{kg}$ load of taurine in subjects with Friedreich's Ataxia (FA), and healthy controls (C), and subjects with Duchenne type muscular dystrophy (MD). Of the FA, 25\% had increased fasting excretion of zinc, and $50 \%$ had increased excretion of zinc following the taurine load. The MD subjects all had increased zinc excretion at all times. The increased zinc excretion did not correlate with increased excretion of taurine. As an index of zinc deficiency, uptake of zinc by erythrocytes was measured in all subjects and in heterozygotes for FA. The pattern of uptake was abnormal for FA and heterozygotes. Hair analysis for zinc showed that 10 of the 12 FA subjects had low values.

We conclude that significant abnormalities in zinc metabolism exist in some, but not all cases of FA. The evidence available does not permit definition of the cause of these abnormalities, whether zinc deficiency or abnormal zinc transport is the primary factor.

RÉSUMÉ: Nous avons mesuré les concentrations de zinc et de taurine dans l'urine à l'état de jeûne et à la suite d'une surcharge en taurine $(4 \mathrm{mg} / \mathrm{kg}$ ) chez des sujets avec ataxie de Friedreich (FA), des témoins en bonne santé (C) et des malades avec une dystrophie musculaire de type Duchenne (MD). Chez les FA, $25 \%$ avaient une excrétion de zinc augmentée à jeun et $50 \%$ une excrétion de zinc augmentée après surcharge en taurine. Les patients MD avaient une excrétion augmentée de zinc en tout temps. L'excrétion de zinc n'est pas en corrélation avec celle de la taurine. Afin d'obtenir un index de la déficience en zinc, nous avons mesuré la captation de zinc par les érythrocytes chez tous les sujets et chez des hétérozygotes obligatoires pour FA. Le patron de captation était anormal chez les FA et leurs hétérozygotes. L'analyse des cheveux montra des valeurs basses de zinc chez 10 des 12 sujets avec Friedreich.

Nous concluons qu'il existe des anomalies significatives du métabolisme du zinc chez certains Friedreich, mais pas chez tous. Avec les données actuelles nous ne pouvons pas dire si ces anomalies résultent d'un déficit en zinc ou d'une anomalie du transport du zinc.

Can. J. Neurol. Sci. 1984; 11:623-625

Zinc is a metal essential in trace amounts for normal health in humans. Zinc deficiency is associated with a disease symptomatology involving the skin, intestine, reproductive organs and immune system (Prasad, 1982).

This metal is cofactor for eighty enzymes implicated in all metabolic pathways, and it has thus not been possible to ascribe the effects of zinc deficiency to deficient activity of a specific enzyme or a particular-metabolic pathway. Unlike other trace metals such as copper and iron, zinc cannot be oxidised or reduced in vivo and so cannot participate in electron transport. Indeed, it is becoming evident that the biological activity of zinc may not reside entirely at the catalytic site, but that its' most important function may be to stabilize the conformation of polypeptide chains and possibly other macromolecules including nucleic acids. A role for zinc in the prevention of peroxidative damage to polyunsaturated fatty acids in cell membranes has been postulated because of its function in stabilizing membrane protein structure (editorial, 1978).
The symptomatology of Friedreich's ataxia (FA) does not resemble that of zinc deficiency. However, it must be remembered that the zinc deficiency referred to is an overall deficiency in all tissues due either to inadequate dietary intake, or to excessive loss such as occurs following burns. It is conceivable that transport of zinc into the cells, or retention of zinc within a cell could be defective even with normal intake and if this occurred in an organ or specific tissue it would give rise to different problems than with classical deficiency. Under these circumstances a situation analogous to vitamin dependency would occur.

Studies being carried out by our group and others (Butterfield and Markesbury, 1980; Huang et al., 1980) support the hypothesis that there is a defect in cell membrane structure and function in FA. Such a defect could be due to a functional deficiency of zinc, or could result in loss of zinc from the membrane, either situation giving rise to a state of "intracellular malnutrition". A further possibility that zinc is implicated in FA comes from 
earlier observations that taurine metabolism is abnormal in this disease and that taurine may modulate the activity of zinc within the membrane by chelation (Barbeau and Donaldson, 1974).

As we were undertaking a re-evaluation of taurine excretion in FA, it seemed opportune to also investigate zinc (a) to see if there was evidence for a generalised zinc deficiency in FA, (b) to determine if FA subjects had a greater urinary loss of zinc and (c) to determine the effect of a taurine challenge on urinary zinc excretion.

\section{Materials and Methods}

Selection of test subjects and chemical analyses are described elsewhere in this journal. Measurement of zinc in urine was made by atomic absorption spectroscopy.

Hair zinc - hair was washed and oxidised by our standard technique (Shapcott and Khoury, 1977), the zinc was then measured by the spectrophotometric technique of Johnson et al. (1977).

Zinc uptake by $R B C$ - A suspension of washed RBCs was incubated at $37^{\circ}$ in balanced salt solution with added zinc ( $\left.100 \mathrm{ug} / \mathrm{dl}\right)$ with trace radioactive zinc. Aliquots were incubated for 15, 30 and 60 minutes, the cells washed twice with BSS then the radioactivity was counted.

\section{RESULTS}

(a) Basal excretion of Zinc (Table 1)

All the controls and family members had basal zinc excretion (after fasting) within the range that we find for healthy subjects. Of the FA subjects, 3 had definitely raised levels. The three MD subjects had raised urinary zinc excretion.

\begin{tabular}{|c|c|c|c|c|c|c|}
\hline \multirow{2}{*}{$\begin{array}{l}\text { Case } \\
\text { No. } \\
\end{array}$} & \multicolumn{2}{|c|}{ Control } & \multicolumn{2}{|c|}{ FA } & \multicolumn{2}{|c|}{ MD } \\
\hline & $\mathrm{Zn} /$ Creat & $\begin{array}{l}\text { Taur/ } \\
\text { Creat }\end{array}$ & Zn/Creat & $\begin{array}{l}\text { Taur/ } \\
\text { Creat }\end{array}$ & Zn/Creat & $\begin{array}{l}\text { Taur } \\
\text { Creat }\end{array}$ \\
\hline 1 & 0.33 & 192 & 0.31 & 2197 & 3.1 & 373 \\
\hline 2 & 0.17 & 656 & 0.30 & 702 & 2.6 & 5151 \\
\hline 3 & 0.31 & 328 & 1.96 & 1590 & 3.0 & 1256 \\
\hline 4 & 0.28 & 437 & 2.0 & 2897 & & \\
\hline 5 & 0.33 & 171 & 0.37 & 381 & & \\
\hline 6 & 0.50 & 120 & 0.85 & 699 & & \\
\hline 7 & & & 0.59 & 182 & & \\
\hline 8 & & & 5.9 & 1283 & & \\
\hline 9 & & & 0.59 & 3201 & & \\
\hline 10 & & & 1.02 & 3760 & & \\
\hline 11 & & & 1.7 & 194 & & \\
\hline 12 & & & 0.38 & 157 & & \\
\hline
\end{tabular}

\section{Range}

Control $0.17-0.50 ; 120-656$

FA $0.31-5.9 ; 157-3760$

MD 2.6-3.1; 373-5151

\section{(b) Response to taurine challenge (Table 2)}

None of the controls showed an increase above normal in the zinc/creatinine ratio following the taurine challenge. Of the FA subjects, 7 had at least one value definitely raised following taurine challenge. The three MD subjects had increased excretion following taurine. There was no direct correlation between the zinc/creatinine ratio and taurine/creatinine ratios.

\begin{tabular}{|c|c|c|c|}
\hline & Control & $\begin{array}{l}\text { Zn/Creat } \\
\text { FA }\end{array}$ & MD \\
\hline Range of $2 \mathrm{hrs}$ & $0.23-0.66$ & $0.45-4.08$ & $2.68-5.8$ \\
\hline $\begin{array}{r}\text { Values }-4 \mathrm{hrs} \\
6 \mathrm{hrs}\end{array}$ & $\begin{array}{l}0.20-1.32 \\
0.32-1.50\end{array}$ & $\begin{array}{l}0.59-5.37 \\
0.43-4.76\end{array}$ & $\begin{array}{l}4.22-8.3 \\
3.12-7.65\end{array}$ \\
\hline $\begin{array}{l}\text { Number of values }>1.5 \\
\text { (upper limit of normal) }\end{array}$ & $0 / 24$ & $16 / 45$ & $11 / 11$ \\
\hline
\end{tabular}

\section{(c) Zinc uptake by RBC (Table 3)}

The mean uptake was not significantly different by Student's t test between FA subjects and controls, except at 30 mins incubation. However rank-sum analysis, which is more reliable with small numbers of samples and different distributions, showed significant differences $(\mathrm{p}<0.05)$ at 30 and 60 minutes, the FA subjects having lower values at 30 mins and higher values at 60 mins.

Table 3: Zn uptake (cpm/gHb) (RBC)

\begin{tabular}{llll}
\hline \hline & \multicolumn{1}{c}{15 mins } & \multicolumn{1}{c}{30 mins } & \multicolumn{1}{c}{60 mins } \\
\hline Patients & $12628 \pm 4514$ & $20676 \pm 6787^{\mathrm{a}}$ & $39764 \pm 13823^{\mathrm{a}}$ \\
Heterozygotes & $14021 \pm 4939$ & $21523 \pm 8143^{\mathrm{a}}$ & $41278 \pm 15564^{\mathrm{a}}$ \\
Controls & $13290 \pm 2988$ & $26825 \pm 4119$ & $35101 \pm 7020$ \\
MD & $17524 \pm 10502$ & $27634 \pm 23343^{\mathrm{a}}$ & $45713 \pm 36109$ \\
\hline
\end{tabular}

a - different from control $\mathrm{p}<0.05$

N.B.: The apparently higher values with the MD subjects (and the very high SD) were because one of the three subjects had a very high uptake of zinc.

(d) Hair zinc level (Table 4)

Seven of the 12 FA subjects had values in the 10 th percentile for healthy young adults. This is highly significant.

\begin{tabular}{|c|c|c|}
\hline \multicolumn{3}{|c|}{$\begin{array}{l}\text { HAIR ZINC LEVELS - } 118,84,100,22,55,232,62,60,61,72,280,156 . \\
\text { INFA }\end{array}$} \\
\hline NORMAL VALUES & $\begin{array}{l}\text { 10th percentile } \\
90 \text { th percentile }\end{array}$ & $\begin{array}{l}100 \mu \mathrm{g} / \mathrm{g} \\
195 \mu \mathrm{g} / \mathrm{g}\end{array}$ \\
\hline CORRELATION WI & rH FASTING Zn/C & reat.: - NS $(=0.105)$ \\
\hline
\end{tabular}

\section{Discussion}

Zinc combines readily with amino acids to form soluble chelates which, in excess, are excreted in the urine. It would be logical to assume, therefore, that the higher urinary zinc levels would be associated with the highest taurine levels but this was not the case. Also, the fact that only three of the twelve FA 
subjects had increased fasting loss of zinc would seem to be incompatible with abnormal zinc loss being a pathognomonic feature of FA. Furthermore, although the zinc excretion was increased in more than a half of the FA subjects following taurine, it was not a constant feature, and did not relate to the degree of excretion of taurine.

These findings indicate, as with other studies carried out on this disease, that abnormalities exist, but are not sufficiently consistent in any instance to appear to be directly associated with the fundamental metabolic defect (Barbeau, 1982).

The MD subjects were included in this study because, as in the case of glucose tolerance, abnormal results in FA subjects could be attributed to physical immobility, and the MD and FA subjects were similarly handicapped. However, the consistently abnormal results in these MD subjects confirm that, because of the nature of their affliction (a defect in muscle metabolism) they cannot be used as controls. The question, then, "are the abnormal results which had been found in the FA subjects due to their physical incapacity?" must remain an open question.

It is possible that because of chronic excessive zinc loss, some of the FA subjects were zinc deficient and therefore would not show a response to a taurine challenge. The demonstration of zinc deficiency by laboratory tests is a highly controversial subject (Shapcott, 1982) and so we used two techniques based on different principles. The first, zinc uptake by RBC, is based on the fact that virtually all of the zinc in RBCs is bound to the enzyme carbonic anhydrase, and so in deficient subjects zinc will be taken up by erythrocytes until the apoenzyme is saturated (Berry et al., 1966). There is indirect support for this in that RBC zinc has been found to be reduced in zinc deficient states (Standstead et al., 1976).

The pattern of zinc uptake by RBC's differed significantly between FA and controls after 30 mins incubation. There was no difference between FA and heterozogotes, nor between controls and heterozygotes. The uptake with the FA subjects varied much more between individuals than it did in the controls.

The second variate we measured was hair zinc. It is well established that trace elements are taken up by hair in proportion to circulating levels and we have previously found low hair zinc levels in subjects with clinical diagnosis of zinc deficiency. The hair zinc levels, with two thirds of FA subjects showing values below the 10th percentile for healthy young adults, are definitely abnormal as a group, indicating a strong probability that the FA subjects are relatively deficient in zinc.

It is evident from these results that there may be significant abnormalities in reabsorption of zinc by the renal tubule in some FA subjects and that this could result in the apparent zinc deficiency in most of the FA subjects investigated in this study. It is impossible to say if an inadequate intake of zinc is a factor and it is therefore necessary to investigate zinc metabolism at the cellular level in cultivated tissue cells.

Our conclusion is that significant abnormalities in zinc metabolism are present in some, but not all cases of Friedreich's Ataxia. Further investigations must be made to determine if this is due to a defect at the cellular level, or to inadequate intake of zinc - or both.

\section{ACKNOWLEDGEMENT}

The studies reported in this paper were supported by " $L$ ' Association Canadienne de l'Ataxie de Friedreich" and "Le Centre de Recherche Médicale", Université de Sherbrooke.

\section{REFERENCES}

Anon (1978) A radical approach to zinc. Lancet 1: 191.

Barbeau A (1982) Friedreich's disease 1982: Etiologic hypotheses - A personal analysis. Can J Neurol Sci 9:243-263.

Barbeau A, Donaldson J (1974) Zinc, taurine and epilepsy. Arch Neurol 30:52-58.

Berry RK, Bell MD, Wright PL (1966) Uptake of zinc by erythrocytes: effects of zinc deficiency. J Nutr 88:284-287.

Butterfield DA, Markesbury WR (1980) Specificity of biochemical and biophysical alterations in erythrocyte membrane in neurological disorders. J Neurol Sci 47:261-264.

Huang YS, Marcel YL, Vezina C, Barbeau A, Davignon J (1980) Lecithin: cholesterol acyltransferase activity and fatty acid composition of erythrocyte phospholipids in Friedreich's ataxia. Can J Neurol Sci 7:429-434.

Johnson DJ, Djuh Yin-Ying (1977) Improved colorimetric determination of serum zinc. Clin Chem 23:1321-1323.

Prasad AS (1982) Clinical disorders of zinc deficiency. In: (Prasad A, Dreosti I, and Hetzel BS, eds), Clinical application of recent advances in zinc metabolism, New York, A.R. Liss, pp 89-95.

Sandstead HH, Vo-Khactu KP, Solomons N (1976) Conditioned zinc deficiencies. In: (Prasad AS, and Oberlease D, eds), Trace Elements in Human Health and Disease, New York, Academic Press, pp 33-.

Shapcott D (1982) Hair and plasma in diagnosis of deficiency. In: (Prasad AS, Dreosti I, and Hetzel B, eds), Clinical applications of recent advances in zinc metabolism, New York, A.R. Liss, pp 121-126.

Shapcott D, Khoury KK (1977) The measurement of volatile chromium in biological materials. Clin Biochem 10:178-180. 